\title{
ENVIRONMENTAL RISK FACTORS IN COASTAL AREA OF WAWATU VILLAGE, MORAMO SUB DISTRICT, NORTH OF SOUTH KONAWE, SOUTHEAST SULAWESI
}

\author{
Hariati Lestari*, Hartati Bahar, Pitrah Asfian, La Ode Ali Imran Ahmad
}

Faculty of Public Health, University of Halu Oleo, Indonesia

\author{
Accepted: 6 September 2017 \\ *Correspondence: \\ Hariati Lestari \\ Department of Epidemiology, Faculty of Public Health, University of Halu Oleo, Indonesia \\ J1. H.E.Mokodompit, Anduonou,Kendari, Indonesia, 93132 \\ E-mail: lestarihariati@yahoo.co.id
}

Copyright: (C) the author(s), YCAB publisher and Public Health of Indonesia. This is an open-access article distributed under the terms of the Creative Commons Attribution Non-Commercial License, which permits unrestricted non-commercial use, distribution, and reproduction in any medium, provided the original work is properly cited.

\begin{abstract}
Aim: This survey study aims to assess and describe environmental risk factors in Wawatu Village, Moramo sub district, North of South Konawe, Southeast Sulawesi.

Methods: There 43 respondents selected using convenience sampling. Data were collected using selfquestionnaire and observation sheet, consisting of physical condition dimension, chemical and biological factors. Data were analyzed using descriptive statistics.

Results: Findings show that $77 \%$ of respondents had a good water condition, however, $77 \%$ of them had no latrines, $93 \%$ had no severage channel, and $63 \%$ no landfills. Some of respondents $(28 \%)$ disposed of ship waste $(28 \%)$ and household waste $(28 \%)$ in the sea. Sadly, $81 \%$ of respondents did not defecate in the toilet. Conclusions: This study provides the evidence that the health environment in Wawatu Village, Moramo sub district, North of South Konawe, Southeast Sulawesi, needs to more attention. Government and Public health workers need to do great efforts in controlling the risk factors, build the health structure, and implement health promotion program in this area.
\end{abstract}

Key words: Environmental factors, coastal area, risks, Southeast Sulawesi

\section{BACKGROUND}

Coastal areas are one area in the environment that is very important to note management of administration, life habitat, and environmental sanitation. ${ }^{1,2}$ Environmental sanitation is one of the priority programs on the international agenda of the Millennium Development Goals (MDGs) aimed at strengthening the culture of clean and healthy living, preventing the spread of environmentbased diseases, improving community capacity, and implementing government policies to improve access to drinking water and basic sanitation on an ongoing basis in achieving the MDGs $2015 .^{3}$

Indonesia is strategically located, namely in the tropics, flanked by two 
continents and two oceans. This strategic location makes Indonesia as a country rich in natural resources, especially coastal. Marine tourism, pond farming, mining and settlement are some examples of high value economic potential. Coastal areas become an attraction for all parties to manage and use it in terms of economic and politics.

Based on Health Act No. 36 of 2009 Chapter XI, the government stated that environmental health efforts are aimed at realizing the quality of a healthy environment, whether physical, chemical, biological, and social that enables everyone to achieve health status as high as possible. Healthy environments include residential neighborhoods, workplaces, recreation areas, and public places and facilities free of wastewater, solids, garbage, hazardous chemicals, contaminated water and air. ${ }^{4}$ The objective of this research was to describe environmental factors such as physical, chemical, and biological factors in coastal areas of Wawatu village.

\section{METHODS}

This was a survey study with a descriptive approach to describe the environmental factors in Wawatu Village, Moramo sub district, North of South Konawe, Southeast Sulawesi. With the overall sample size in this study was 43 respondents selected using convenience sampling. Data were collected using questionnaire and observation sheet developed by the researcher, consisting of physical condition, chemical and biological factors. The researcher has confirmed that all respondents have obtained an appropriate informed consent. Data were analyzed using descriptive statistics.

\section{RESULTS}

Table 1 shows that $77 \%$ of the physical condition of water was good, however, $77 \%$ of respondents had no latrines, $93 \%$ had no severage channel, and $63 \%$ had no landfills.

Table 1. Distribution of Physical Conditions in Wawatu Village, North Moramo District, South Konawe Regency, Southeast Sulawesi

\begin{tabular}{|l|c|c|}
\hline \multirow{2}{*}{ Physical Conditions } & \multicolumn{2}{|c|}{ Respondents } \\
\cline { 2 - 3 } & f & \% \\
\hline Physical condition of water (smelling, feeling, color) \\
\hline Yes & 10 & 23 \\
\hline No & 33 & 77 \\
\hline Ownership of latrines & 10 & 23 \\
\hline Yes & 33 & 77 \\
\hline No & 3 & 7 \\
\hline Ownership of sewerage channel & 40 & 93 \\
\hline Yes & 16 & 37 \\
\hline No & 27 & 63 \\
\hline Ownership of landfills & $\mathbf{4 3}$ & $\mathbf{1 0 0}$ \\
\hline Yes &
\end{tabular}


Table 2. Chemical Factors in Wawatu Village, North Moramo District, South Konawe Regency, Southeast Sulawesi

\begin{tabular}{|l|c|c|}
\hline \multirow{2}{*}{ Chemical factor } & \multicolumn{2}{|c|}{ Respondents } \\
\cline { 2 - 3 } & f & \% \\
\hline The habit of catching fish in the sea & 28 \\
\hline Yes & 12 & 72 \\
\hline No & 31 & 28 \\
\hline Disposal of ship wastes at sea & 72 \\
\hline Yes & 12 & \\
\hline No & 31 & 37 \\
\hline Disposal of household waste at sea & 16 & 63 \\
\hline Yes & 27 & $\mathbf{1 0 0}$ \\
\hline No & $\mathbf{4 3}$ & \\
\hline \multicolumn{1}{|c|}{ Total } & & \\
\hline
\end{tabular}

Table 2 shows that $28 \%$ of respondents had a habit of catching fish in the sea, $28 \%$ of them disposed of ship waste at sea, and $37 \%$ disposed of household waste at sea.

Table 3. Distribution of Biological Factors in Wawatu Village District of North Moramo Regency of South Konawe Southeast Sulawesi

\begin{tabular}{|l|c|c|}
\hline \multirow{2}{*}{ Biological Factors } & \multicolumn{2}{|c|}{ Respondent } \\
\cline { 2 - 3 } & f & \% \\
\hline Hand washing before and after eating & & 74 \\
\hline Yes & 32 & 26 \\
\hline No & 11 & \\
\hline Hand washing after defecation & 40 & 93 \\
\hline Yes & 3 & 7 \\
\hline No & & \\
\hline Bath one day (>1 time) & 35 & 81 \\
\hline Yes & 8 & 19 \\
\hline No & & \\
\hline Defecation in the toilet & 8 & 19 \\
\hline Yes & 35 & 81 \\
\hline No & 33 & \\
\hline Water cooking habits & 10 & 23 \\
\hline Yes & & \\
\hline No & 34 & 91 \\
\hline Keep nail cleaning (every 2 weeks) & 9 & 9 \\
\hline Yes & 40 & 93 \\
\hline No & 3 & 7 \\
\hline Habits of wearing footwear outside the house & $\mathbf{4 3}$ & $\mathbf{1 0 0}$ \\
\hline Yes & & \\
\hline No & & \\
\hline &
\end{tabular}

Table 3 shows that the majority of respondents had a good habit of hand washing before and after eating (74\%), after defecation (93\%), habit of wearing footwear outside the house (93\%), cooking water $(77 \%)$, bathing more than one time $(81 \%)$, and keep nail cleaning (91\%). However, $81 \%$ of respondents did not defecate in the toilet. 


\section{DISCUSSION}

This study described the environmental factors in terms of physical condition of water, chemical and biological factors. Findings showed that the physical condition of the water source in Wawatu village is quite good, but the problem is the ownership of latrines, severage channel, and landfills. The absence or shortage of proper sanitation and poor waste management are the main causes of the disease. Microbial contamination and water-borne diseases are caused by improper sanitation systems in some developing countries. ${ }^{5}$

On the other hand, this study also described that some respondents still had a habit of catching fish in the sea, disposing ship and household waste at sea, which potentially pollute the coastal and marine environment. ${ }^{6}$ In addition, fishing activities such as water transport and disposal from shipyards contribute to the increase in metal content. ${ }^{7}$ The heavy metal content that accumulates in seawater and sediment will enter into the food chain system and affect the life of the organism. ${ }^{8}$

Waste is one of the main forces driving the destruction of coral reefs around the world. ${ }^{9}$ Waste contains many types of disease-causing organisms including $E$-coli, which can cause various health problems such as diarrhea, severe abdominal pain, and vomiting. Pollution of waste also affects the ecosystem. Furthermore, waste contains high levels of nutrients such as phosphates and nitrates that can affect rivers, lakes and seas through eutrophication caused by enrichment of nutrients. ${ }^{9}$

However, findings also showed that the majority of respondents had a good habit of hand washing before and after eating, after defecation, habit of wearing footwear outside the house, cooking water, bathing more than one time, and keep nail cleaning. These habits need to be maintained. Research found that hand washing with soap could reduce morbidity diarrhea in the range $30 \%$ to $47 \%$, even higher than diarrhea reduction by providing clean water $(27 \%){ }^{10}$ Hand washing is done not only when our hands are dirty, but also when preparing food, before meals and feeding the child, and after defecating. ${ }^{11}$

But, one of the major concerns in the findings of the study is defecation in toilet. In fact, $81 \%$ of respondents did not defecate in the toilet, which tells the risk factors are identified. A case-control study of risk factors for diarrhea in children under three years in Burkina Faso reported that improper disposal of feces was associated with a $50 \%$ of the increase of the risk of diarrhea morbidity compared with disposal in latrines. ${ }^{10}$ Similar study has also shown that failure to dispose of feces properly was associated with an increased incidence of diarrheal diseases of $30-50 \%$ in children. ${ }^{12}$

\section{CONCLUSION}

This study provides the evidence that the health environment in Wawatu Village, Moramo sub district, North of South Konawe, Southeast Sulawesi, needs to be improved, especially in terms of the structure (ownership of latrines, severage channels, and landfills); and process (the habits of disposal of wastes in the sea, defecation in toilet). Government and Public health workers need to pay more attention in controlling the risk factors and build the health structure, and implement health promotion program in this area.

\section{REFERENCES}

1. Tosepu R, La Ode Ali Imran
Ahmad DSE. Kesehatan
Masyarakat Pesisir: Yayasan Cipta
Anak Bangsa (YCAB); 2016.


2. Clark JR. Coastal zone management handbook: CRC press; 1995.

3. Organization WH. Health in 2015: from MDGs, Millennium Development Goals to SDGs. Sustainable Development Goals. 2015:204.

4. Presiden R. Undang-Undang Republik Indonesia No. 36 Tahun 2009 Tentang Kesehatan. Presiden Republik Indonesia, Jakarta. 2009.

5. Rahman SH, Ahmed S, Jakariya M. Investigation of shallow tube-well water quality considering the influence of nearby latrines in a rural village of Bangladesh. IAHS publication. 2009;20:299.

6. Ika I, Tahril T, Said I. The Analysis of Lead $(\mathrm{Pb})$ and Iron (Fe) Metals in The Sea Water of Coastal Area of Taipa's Ferry Harbor Subdistrict of North Palu. Jurnal Akademika Kimia. 2013;1(4).

7. Zhang G, Liu D, Wu H, Chen L, Han Q. Heavy metal contamination in the marine organisms in Yantai coast, northern Yellow Sea of China. Ecotoxicology. 2012;21(6):1726-1733.

8. Said I, Jalaluddin MN, Upe A, Wahab AW. Penetapan konsentrasi logam berat krom dan timbal dalam sedimen estuaria Sungai Matangpondo Palu. CHEMICA. 2012;10(2):40-47.
9. Bherer L. Cognitive plasticity in older adults: effects of cognitive training and physical exercise. Annals of the New York Academy of Sciences. 2015;1337(1):1-6.

10. Curtis V, Cairncross S, Yonli R. Review: Domestic hygiene and diarrhoea-pinpointing the problem. Tropical medicine \& international health. 2000;5(1):22-32.

11. Luby SP, Halder AK, Tronchet C, Akhter S, Bhuiya A, Johnston RB. Household characteristics associated with handwashing with soap in rural Bangladesh. The American journal of tropical medicine and hygiene. 2009;81(5):882-887.

12. Cairncross S, Shordt K, Zacharia S, Govindan BK. What causes sustainable changes in hygiene behaviour? A cross-sectional study from Kerala, India. Social Science \& Medicine. 2005;61(10):22122220 .

Cite this article as: Lestari $\mathrm{H}$, Bahar $\mathrm{H}$, Asfian P, Ahmad LOAI. Environmental Risk Factors in Coastal Area of Wawatu Village, Moramo Sub District, North of South Konawe, Southeast Sulawesi. Public Health of Indonesia 2017;3(3):107-111 